\title{
Rates of deformation, uplift, and landscape development associated with active folding in the Waipara area of North Canterbury, New Zealand
}

\author{
Andrew Nicol ${ }^{1}$ \\ Department of Geology, University of Canterbury, Christchurch, New Zealand
}

\author{
Brent Alloway \\ Department of Geology, Auckland University, Tamaki Campus, Auckland, New Zealand \\ Philip Tonkin \\ Department of Soil Science, Lincoln University, Canterbury, New Zealand
}

\begin{abstract}
Analysis of the geometry and ages of faulted and tilted late Quaternary fluvial terraces and their associated cover beds provide evidence of active folding at three localities in the Waipara area of North Canterbury, New Zealand. Terrace survey data, the occurrence of the approximately 22.6kyr-old Aokautere Ash, and examination of soil profiles indicate that folding has continued into the late Holocene but that the amounts and rates of deformation are locally variable. Rates of uplift in the Waipara area are compared with those derived from marine terraces preserved at the Pacific coast, east of the study area. Results indicate that rates of measurable deformation reach a maximum along the Waipara range front, where bedrock deformation is most intense and shortening rates of up to $5.57 \pm 0.69 \% / 100 \mathrm{kyr}$ occur. Across the coastal ranges the average rate of shortening is $0.8 \pm 0.4 \% / 100 \mathrm{kyr}$, which corresponds with an absolute shortening rate of $1.4 \pm$ $0.6 \mathrm{~m} / \mathrm{kyr}$ and represents only a small proportion of the predicted plate motion vector in this region. Uplift rates range from $0-1.83 \mathrm{~m} / \mathrm{kyr}$ for a late last glacial fluvial terrace and from 1.36-2.16 m/kyr for three marine terraces. Fluvial and marine terrace uplift rates vary in accord with the geometries of the folds in bedrock, and the spatial pattern of uplift directly reflects fold growth. The structure contour pattern of folded surfaces provides a first approximation to the spatial pattern of uplift. Differential uplift due to folding accounts for up to approximately $55-75 \%$ of the total uplift and has produced folds with structural relief of about $1300 \mathrm{~m}$ (i.e., amplitudes of $600-700 \mathrm{~m}$ ). These folds have formed over the
\end{abstract}

\footnotetext{
${ }^{1}$ Now at Earth Sciences Department, University of Liverpool, Liverpool, England.
}

Copyright 1994 by the American Geophysical Union.

Paper number $94 \mathrm{TC} 01502$.

0278-7407/94/94TC-01502\$10.00 last $0.8 \pm 0.4 \mathrm{~m} . \mathrm{y}$. since the onset of Quaternary deformation in the Waipara region.

\section{Introduction}

The fundamental prerequisite for documenting active fold growth is the recognition of late Quaternary marker horizons, which are of sufficient age and lateral extent to display gradients that depart from their initial orientation. In New Zealand many such markers have been used to document folding; these include marine terraces [e.g., Singh, 1971; Ghani, 1978; Berryman, 1993a, b], fluvio-glacial terraces [Suggate, 1987], and wave-planed surfaces [Lewis, 1971]. Although the analysis of active folding is often difficult owing to the continuous nature of deformation and the absence of suitable markers, it must be recognized that folding may account for a significant component of the total strain. In this context the analysis of active folding is extremely important if rates of deformation and potential seismic hazard are to be adequately characterized. Our observations also suggest that fundamental relationships exist between landscape development and the distribution of folds in areas of active deformation.

In an attempt to characterize active folding in the Waipara area of North Canterbury, New Zealand (Figure 1) we have integrated the analysis of bedrock structure, Quaternary stratigraphy, geomorphology, and pedology. Data have been collected from three different localities across the Waipara Syncline, near the township of Waipara (Figure 1). Fold geometry data, principally derived from altitudinal surveying, include disrupted cover bed stratigraphy and deformed fluvial terrace surfaces. Geometric data are complemented by age determinations provided by the radiometrically dated and laterally extensive Aokautere Ash, a radiocarbon date and detailed analysis of soil profile morphologies. The study has allowed conclusions to be drawn about the rates of shortening and uplift associated with folding, the age of cover beds, fluvial terrace surfaces and their deformation, and the relationships of active folding to landscape development in the coastal ranges of North Canterbury. 

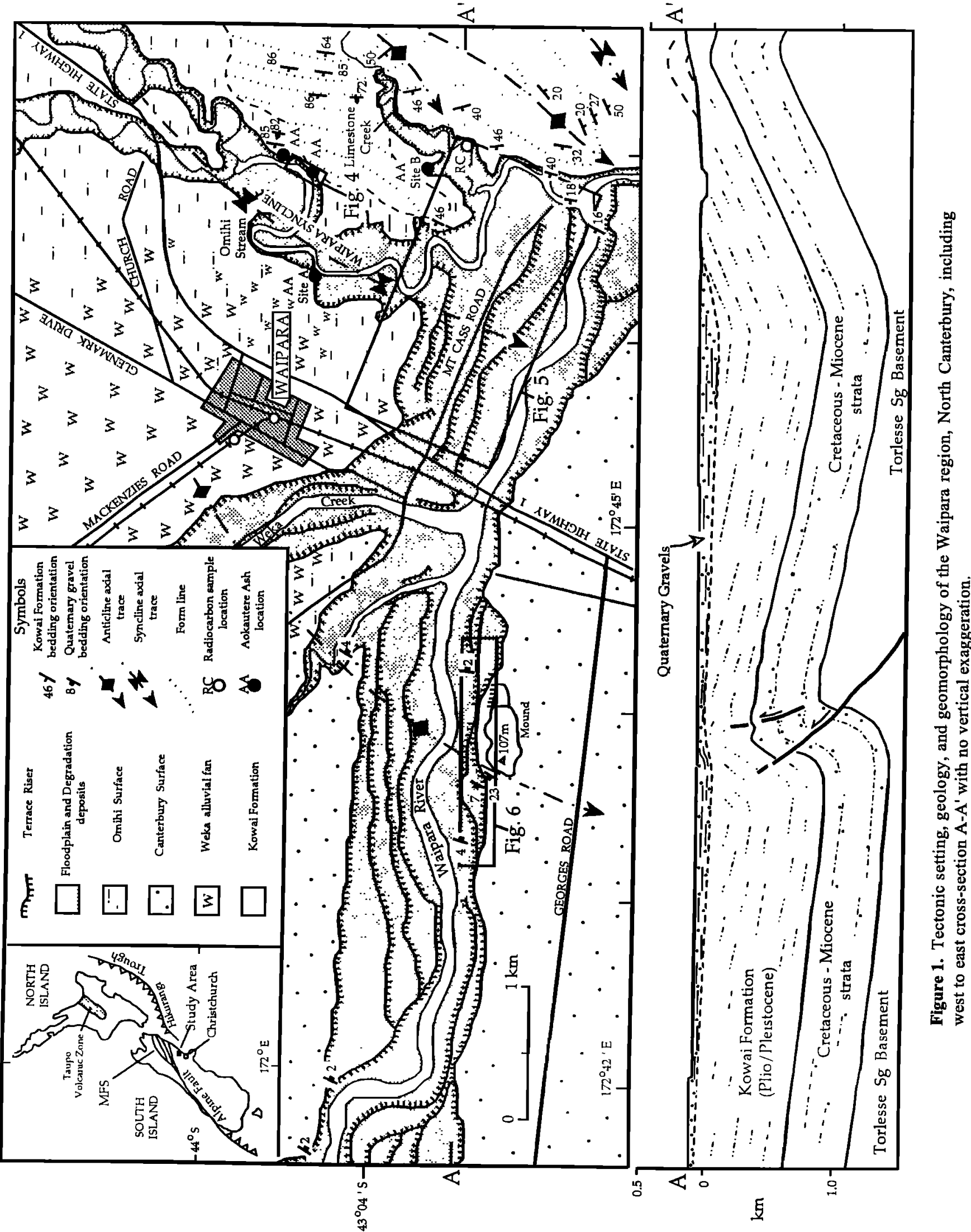


\section{North Canterbury Geology}

\section{Structure}

North Canterbury is located on the southeastern margin of the Marlborough Fault System (MFS), a portion of the obliquely convergent New Zealand plate boundary dominated by right-lateral strike-slip faulting. The style of faulting at the surface in North Canterbury is dominated by reverse faults and thrusts that mainly strike northeast and dip to the southeast. These faults are closely associated with a number of asymmetric macroscopic folds, which are developed within an approximately $1-\mathrm{km}$ thick sequence of late Cretaceous-early Pleistocene sedimentary rocks. The folds are frequently characterized by steep northwest limbs ( $60^{\circ}$ to overturned dips) and shallow southeast limbs $\left(10-30^{\circ}\right.$ dips $)$, with the steep limb often being faulted. Collectively, the faulting and folding have accommodated approximately $12-15 \%$ northwestsoutheast regional shortening between the Pacific coast and Hope Fault [Nicol, 1991], the southernmost element of the MFS.

The topography is dominated by a series of northeast trending valleys and ridges that reflect the influence of the underlying structures. The ridges are composed of indurated Mesozoic graywacke and argillite basement (Torlesse Supergroup) and represent the exposed cores of macroscopic anticlines, which are generally confined to the hanging walls of the faults. The valleys are located on the footwalls of the faults, coincident with the major synclinal structures. The largest of these valleys is the Culverden Basin, a structural depression that, like many similar structures in North Canterbury, contains an unknown, but probably small $(<200$ m) thickness of Quaternary gravel deposits. Active faults bound the northwest side of the ridges and displace both geomorphic surfaces and Quaternary gravels [Wilson, 1963; Gregg, 1964; Maxwell, 1964; Cowan, 1992a].

Structures in the Waipara area (Figure 1) constitute part of the North Canterbury fold and thrust (or reverse fault) belt. Local folds are characterized by two anticline-syncline pairs that strike approximately NNE and verge westward. The most dominant of these structures are the Waipara Syncline and Black Anticline, which are separated to the north by the Omihi Fault, a major range-bounding structure. Yousif [1987] showed that folds immediately adjacent to the study area, including the Black Anticline, are currently active. Active folding extends westward across the Waipara Syncline for at least $15 \mathrm{~km}$ [Campbell and Nicol, 1992].

\section{Geomorphic Surfaces}

In the Waipara area, five groups of geomorphic surfaces are identified using soil morphology, elevation, and available age data. The oldest, named the Teviotdale Surface [Wilson, 1963], is of small areal extent and characterized by isolated loess-mantled remnants preserved to the south and southeast of the Waipara River. This surface is not studied here.

The next youngest and more extensive surface was named "Canterbury Surface" [Wilson, 1955], and the gravels that immediately underlie this surface were referred to as "Canterbury Gravels". Harris [1982] recognized that Canterbury Gravels within the Waipara-Omihi valley were deposited by a slow flowing, meandering river channel that re- peatedly migrated across a floodplain dominated by a mosaic of grassland-shrubland. These sediments were inferred by Harris to correlate with those deposited during and since the last glacial maxima (approximately $12-24 \mathrm{kyr}$ ago; [see Pillans et al., 1993] based on the apparent absence of loess, glacial, or periglacial deposits, the slight degree of weathering, and lack of stream dissection. This estimate was supported by a conventional radiocarbon age of 10,550 \pm 150 years B.P. obtained from a Hyridella shell sample within an upper silt unit, but such shell samples can be subject to contamination, and we regard this date as a minimum. Although the uppermost portion of the meander stream sequence was thought to represent deposition during the last glacial maxima (LGM), the entire meander stream sedimentary succession represents progressive infilling of a basin along the hinge of the Waipara Syncline during the late Quaternary. For the purposes of this study the late last glacial aggradation surface in the Omihi-Waipara valley will subsequently be referred to as the "Omihi Surface" (see Figure 1 for lateral extent).

The Omihi aggradation surface is underlain by up to approximately $3 \mathrm{~m}$ of calcareous silts, sands, and gravels, which may contain or overlie a silicic tephra (Figure 2) erupted from the Taupo Volcanic Zone, which is here correlated to the approximately 22.6-kyr-old Aokautere Ash (see next section). The presence of this tephra below the Omihi Surface suggests that the terrace is necessarily younger than approximately $22.6 \mathrm{kyr}$. The mature nature of the soil profiles (vertic melanic soils, see Figure 5) suggest that the surface is unlikely to be Holocene in age. We infer that the terrace surface formed during late last glacial (approximately $12 \pm 2 \mathrm{kyr}$ ago) aggradation of Omihi Stream. The Canterbury and Omihi aggradation surfaces appear to coalesce and grade to the same height in the general vicinity of Waipara township (Figure 1).

The fourth geomorphic surface is Weka Fan, characterized by a series of narrow alluvial ridges that extend east and southeast from the mouth of Weka Pass across State Highway 1 (Figure 1). Southeast of Weka Pass, the Weka Fan is clearly higher than the older Canterbury Surface, and lobes of alluvium overlie loess which was presumably derived from the Canterbury Gravels. A possible correlative of this loess-mantled surface occurs as a small, eastward dipping remnant preserved on the eastern side of the Mound (Figure 1).

Below the Canterbury and Omihi Surfaces, flights of river terraces step down to the active floodplains. These surfaces are characteristically stony, with rudimentary soil profiles that are predominantly $<0.25 \mathrm{~m}$ in thickness (orthic brown soils, Figure 5) and are interpreted as degradation terraces. A radiocarbon date from charcoal sampled from beneath a degradation terrace in Limestone Creek (Figure 1) produced a conventional radiocarbon age of $1008 \pm 63$ years B.P. (NZ7957). The sample is inferred to date ponding of Limestone Creek behind the second highest Waipara River terrace. This, together with the immature soil profiles, suggests that degradation of the Waipara River from the second highest terrace to its present level (approximately $20 \mathrm{~m}$ ), occurred during the late Holocene.

\section{Occurrence and Recognition of the Aokautere Ash}

The largest and most widespread late Pleistocene silicic air fall tephra, Aokautere Ash Member of the Kawakawa Tephra, 
Site A

Omihi Stream

(N34/915943)

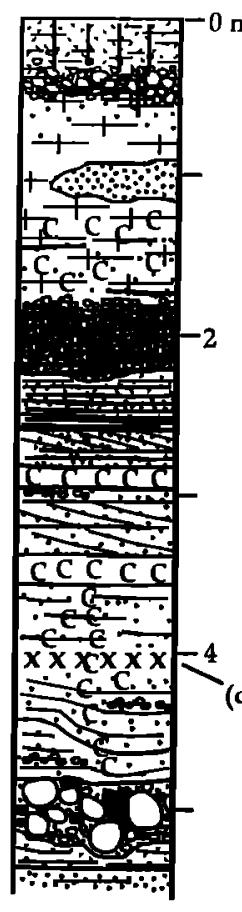

Weka Fan alluvial gravels (dominantly Torlesse lithologies)

well sorled medium sand

laminated to weak X-bedded (mm-dcm) well sorted, calcareous fluvial silts and sands.

c. $5 \mathrm{~cm}$ thick SILICIC TEPHRA BED (distal correlative of Aokautere Ash)

laminated to weak

X-bedded (mm-dcm) well sorted, calcareous fluvial silts and sands with moderately sorted gravel interbeds containing mixed Amuri Limestone and Torlesse lithologies

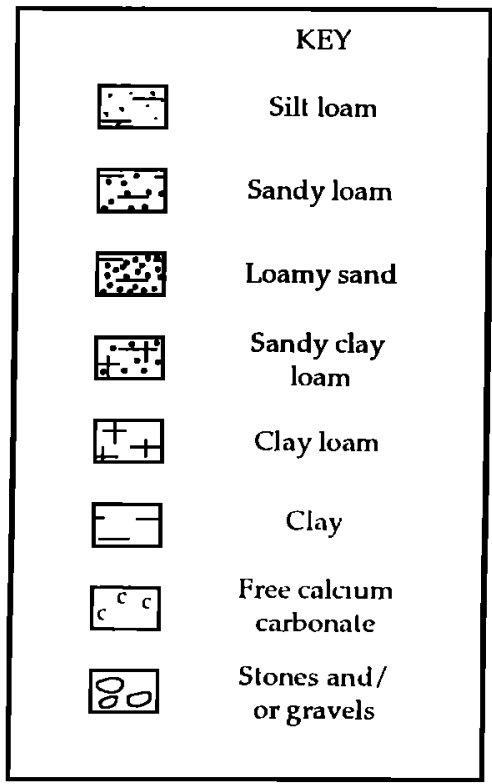

Site B

Limestone Creek (N34/924935)

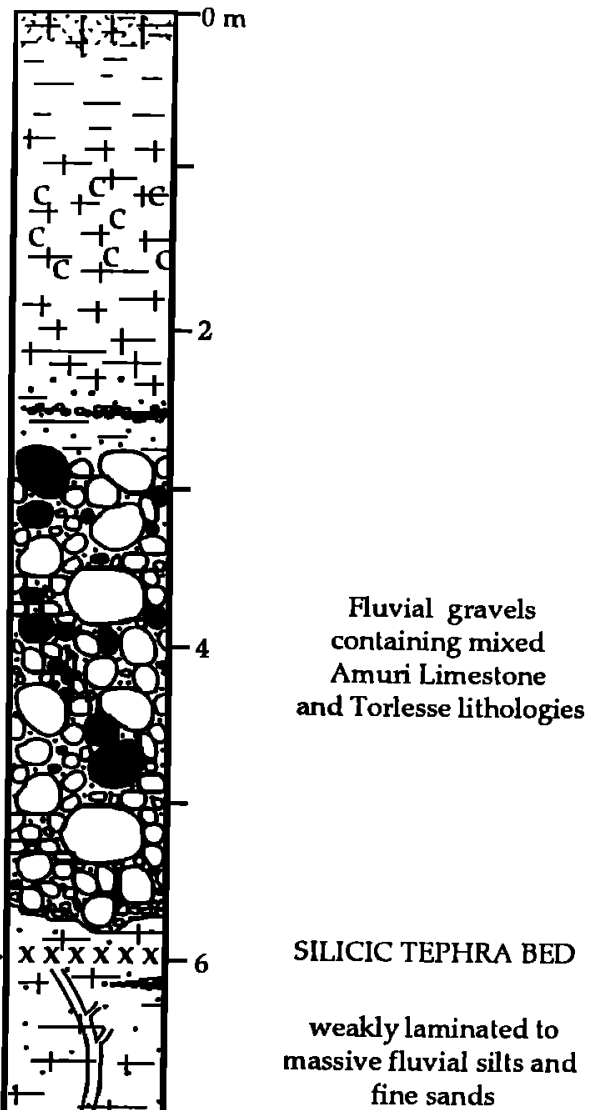

Fluvial gravels containing mixed Amuri Limestone and Torlesse lithologies $-10$ (ant?

Figure 2. Stratigraphy enclosing the Aokautere Ash correlative at site A along Omihi Stream and site B along Limestone Creek, Waipara (see Figure 1). 
was erupted from the Lake Taupo area (see Figure 1 inset) at approximately $22.6 \mathrm{kyr}$ ago [Wilson et al., 1988; Froggatt and Lowe, 1990; Pillans et al., 1993]. This air fall tephra has proven to be extremely useful in regional studies because it defines an isochronous horizon for correlation and age control of LGM loess, peat, and colluvial deposits, as well as geomorphic surfaces and associated soils. This air fall tephra is found extensively within central and southern North Island [Milne, 1973; Palmer, 1982], as well as northern South Island [Eden, 1983; Campbell, 1986]. Isolated occurrences have also been reported from western South Island [Mew et al., 1986]; however, in North Canterbury, Aokautere Ash has only been previously reported from one site just southeast of the study area, near the township of Amberley [Kohn, 1979]. Here the tephra was fission track dated at $20,300 \pm 7100$ years B.P. In other areas of central and southern South Island, where this tephra is absent, age determinations of late Quaternary geomorphic surfaces and/or soils have been mostly restricted to using ${ }^{14} \mathrm{C}$ and thicknesses of weathering rinds on graywacke sandstone clasts [e.g., Chinn, 1981; Knuepfer, 1988; Campbell and Nicol, 1992].

In this study, four new localities of a silicic tephra are identified and described in the vicinity of Waipara in North Canterbury (Figure 1). Here this tephra occurs typically as an intermittently exposed approximately $\leq 0.05-\mathrm{m}$ thick horizon encapsulated within fine-grained, calcareous fluviatile deposits (Figure 2). This tephra can be readily distinguished from similarly thick, very pale brown to white $\mathrm{CaCO}_{3}$ layers on the basis of its characteristic pinkish color (5YR 7/3) and silt-grade, glassy texture.
Aokautere Ash is the only macroscopic silicic tephra extensively present in late Quaternary strata. Consequently, its thickness and stratigraphic position within LGM loess in most areas is usually distinctive enough to permit its reliable identification. However, in the Waipara area the silicic tephra occurs enclosed within late Quaternary fluviatile deposits but has yet to be found as a discrete layer within LGM loess of the area; its identity as Aokautere Ash therefore required confirmation by glass shard chemistry.

Glass shards of samples from two Waipara localities were analyzed for major elements using electron microprobe (EMP) analysis. The EMP analyses (Table 1) confirm that this silicic tephra cannot be differentiated from similar analyses of Aokautere Ash obtained from its type section and a number of distal localities. However, these analyses are clearly distinguishable from other widespread Pleistocene silicic tephras erupted from the Taupo Volcanic Zone, as illustrated in the $\mathrm{CaO}-\mathrm{FeO}-\mathrm{K}_{2} \mathrm{O}$ ternary diagram (Figure 3 ).

\section{Evidence for Active Folding}

\section{Fault Bank Locality}

This locality was first described by Harris [1982]. Here, approximately $10-20 \mathrm{~m}$ of Quaternary fluviatile beds rest with angular unconformity on Plio-Pleistocene Kowai Formation bedrock (Figure 4; see Figure 1 for location). These fluvial beds, characterized by pebbly to clayey sediments derived principally from post-Torlesse lithologies, are both faulted

Table 1. Average Major Element Composition of Glass Shards From Aokautere Ash at Its Type Section Compared With Its Distal Correlatives

\begin{tabular}{|c|c|c|c|c|c|}
\hline & \multicolumn{3}{|c|}{$\begin{array}{l}\text { Aokautere Ash Member of the Kawakawa Tephra } \\
\text { Formation }\end{array}$} & \multirow[b]{2}{*}{$\begin{array}{c}\text { Waipara } \\
\text { This Study }^{\mathrm{b}} \text {, } \\
\text { Site A } \\
\end{array}$} & \multirow[b]{2}{*}{$\begin{array}{c}\text { Waipara } \\
\text { This Study } \\
\text { Fault Bank }\end{array}$} \\
\hline & Type Section $^{\text {a }}$ & Taranaki $^{\mathbf{a}}$ & Amberley ${ }^{2}$ & & \\
\hline $\mathrm{SiO}_{2}$ & $79.01 \pm 0.38$ & $79.35 \pm 0.30$ & $78.81 \pm 0.44$ & $77.55 \pm 0.43$ & $77.73 \pm 0.36$ \\
\hline $\mathrm{Al}_{2} \mathrm{O}_{3}$ & $12.15 \pm 0.30$ & $12.40 \pm 0.12$ & $12.44 \pm 0.15$ & $12.65 \pm 0.26$ & $12.48 \pm 0.23$ \\
\hline $\mathrm{TiO}_{2}$ & $0.13 \pm 0.03$ & $0.12 \pm 0.03$ & $0.11 \pm 0.03$ & $0.15 \pm 0.05$ & $0.17 \pm 0.05$ \\
\hline $\mathrm{FeO}$ & $1.15 \pm 0.10$ & $1.19 \pm 0.11$ & $1.18 \pm 0.08$ & $1.20 \pm 0.13$ & $1.16 \pm 0.12$ \\
\hline $\mathrm{MgO}$ & $0.12 \pm 0.02$ & $0.12 \pm 0.01$ & $0.12 \pm 0.02$ & $0.15 \pm 0.03$ & $0.20 \pm 0.07$ \\
\hline $\mathrm{CaO}$ & $1.05 \pm 0.09$ & $1.07 \pm 0.09$ & $1.02 \pm 0.09$ & $1.08 \pm 0.09$ & $1.10 \pm 0.09$ \\
\hline $\mathrm{Na}_{2} \mathrm{O}$ & $3.31 \pm 0.21$ & $2.47 \pm 0.37$ & $3.35 \pm 0.22$ & $3.87 \pm 0.19$ & $3.87 \pm 0.26$ \\
\hline $\mathrm{K}_{2} \mathrm{O}$ & $3.07 \pm 0.25$ & $3.08 \pm 0.10$ & $2.96 \pm 0.37$ & $3.12 \pm 0.17$ & $3.07 \pm 0.15$ \\
\hline $\mathrm{Cl}$ & - & $0.18 \pm 0.02$ & - & $0.23 \pm 0.03$ & $0.22 \pm 0.06$ \\
\hline $\mathrm{H}_{2} \mathrm{O}$ & $5.65 \pm 1.62$ & $7.14 \pm 0.98$ & $3.41 \pm 1.40$ & $6.10 \pm 1.04$ & $5.48 \pm 1.26$ \\
\hline$n$ & 74 & 15 & 11 & 19 & 21 \\
\hline
\end{tabular}

All major element determinations were made on a JEOL JXA-733 electron microprobe housed at Victoria University of Wellington. Analyses were determined using a beam current of $8 \mathrm{nA}$, beam diameter of $20 \mathrm{~mm}$, and $3 \times 10$-s peak counts (meaned). Values are in weight-percent oxide, recalculated to $100 \%$ on a fluid-free basis. $\mathrm{H}_{2} \mathrm{O}$ is by difference from $100 \%$; total iron expressed as FeO; $n$ is number of analyses. The major element composition of internal glass standards KN-18, VG-99, and VG-568 were routinely analyzed to check and correct for machine drift. See Figure 2 for Site A and Figure 3 for Fault Bank.

a Analyst was P. Froggatt.

'Analyst was D. Manning. 


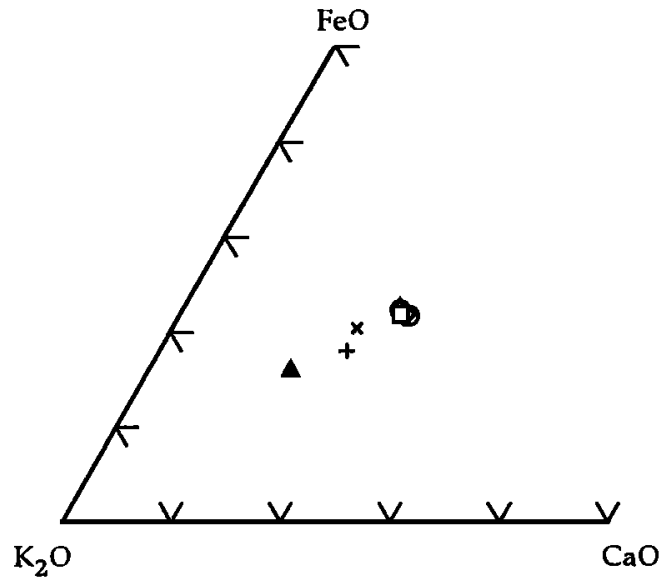

\begin{tabular}{|c|c|c|c|}
\hline 0 & $\begin{array}{c}\text { Aokautere Ash distal correlative } \\
\text { Waipara - Site A } \\
\text { Aokautere Ash distal correlative }\end{array}$ & + & $\begin{array}{l}\text { distal Rotoehu Tephra (55 ka) - } \\
\text { Taranaki, western North Island } \\
\text { (from Alloway et al., 1994) }\end{array}$ \\
\hline & Waipara - Fault Bank & \multirow[t]{2}{*}{$\Delta$} & Rangitawa Tephra (350 ka) — \\
\hline 口 & $\begin{array}{l}\text { Aokautere Ash from type section - } \\
\text { hangamata Road, Central North Island }\end{array}$ & & $\begin{array}{l}\text { type section, southern North Island } \\
\text { (from Alloway et al., 1993) }\end{array}$ \\
\hline$\diamond$ & $\begin{array}{l}\text { distal Aokautere Ash - } \\
\text { Taranaki, western North Island } \\
\text { (from Allowbay et al., 1994) }\end{array}$ & \multirow[t]{2}{*}{$\mathbf{x}$} & $\begin{array}{l}\text { Potaka Tephra (1.05 Ma) }- \\
\text { type section, southern North Island } \\
\text { (from Alloway et al., 1993) }\end{array}$ \\
\hline$\Delta$ & $\begin{array}{l}\text { distal Aokautere Ash - } \\
\text { Amberley, east-central South Island }\end{array}$ & & \\
\hline
\end{tabular}

Figure 3. FeO-K, $\mathrm{O}-\mathrm{CaO}$ ternary plot showing the composition of Aokautere Ash compared with several other widespread Pleistocene tephra erupted from the Taupo Volcanic Zone. Ticks on the diagram are at $10 \%$ intervals.

and tilted with intense local deformation adjacent to a mesoscale fault. Away from the fault the fluvial beds thicken and contain the approximately 22.6-kyr-old Aokautere Ash. Structure contours constructed on the top of the $0.05-\mathrm{m}$ thick ash horizon indicate that it dips at approximately $9^{\circ}$ (Table 2) SSW but has a much reduced apparent dip in the bank exposure of Figure 4. Below the ash horizon the beds become increasingly tilted, from which we infer that the cover beds increase in age toward the unconformity surface and that the onset of folding began well before cover bed deposition. To qualify these age relationships, we have used rates of shortening for the period since ash deposition and dip data from the pre-ash beds (see Table 2 for further details).

The fault exposed at the Fault Bank locality (Figure 4) is a mesoscale structure that strikes southeast at an oblique angle to the main folds. Slickenside striations on the fault plane suggest that it has accommodated dip-slip movement, while two gravel marker horizons, G1 and G2, have been displaced in a reverse sense by 3.8 and $5.7 \mathrm{~m}$, respectively (Figure 4). The fault has accommodated a total of at least $5.7 \mathrm{~m}$ displacement during two or more events since the deposition of the top of the G2 gravel bed. The top of the G2 gravel unit is eroded, so this figure is a minimum. Aokautere Ash perceptibly thins toward, and is apparently deformed adjacent to the fault, which suggests that the last fault movement postdates approximately $22.6 \mathrm{kyr}$. Using the age derived for the top of the basal gravel bed (approximately $78 \pm 19 \mathrm{kyr}$, see Age Estimates section), a minimum slip rate of $0.073 \pm 0.019$ $\mathrm{m} / \mathrm{kyr}$ is calculated for the fault.

Shortening Calculations. The age and dip of the Aokautere Ash are used to calculate both the amount and rate of local finite shortening for the period since ash deposition at the Fault Bank locality. These calculations are based on the following assumptions: (1) the ash horizon and all beds for which ages have been calculated were approximately horizontal prior to deformation and (2) the ash horizon and bed dips are indicative of folding achieved by bed rotation about a horizontal axis associated with constant rates of shortening.

The first assumption appears to be reasonable, given that the ash horizon is contained within fluvial pebbly silts and sands, where present floodplain gradients for Omihi Stream and the Waipara River are generally $<0.3^{\circ}$. The mechanics of fold development are not addressed in detail here. However, given that the folds are developed in late Cretaceous and younger strata, which generally do not exceed $1.5 \mathrm{~km}$ in thickness, and that the active folding we are describing is now occurring at the ground surface, we conclude that the folds formed at shallow levels $(<1.5 \mathrm{~km})$ in response to buckling. The absence of abundant slickensides and/or striated bedding surfaces suggests that at an outcrop scale, bedding plane slip 


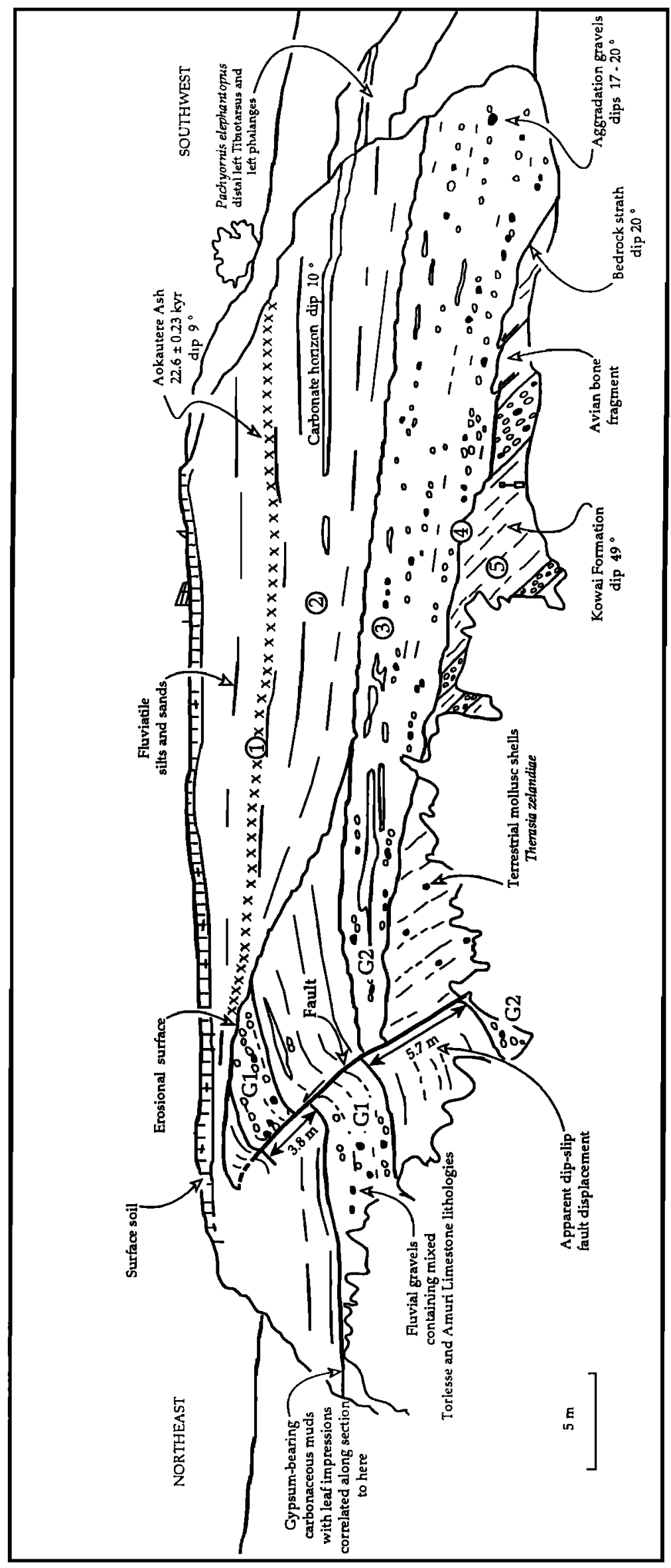

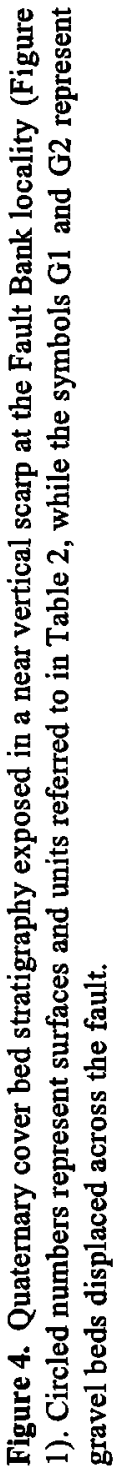


Table 2. Age Estimates for Cover Beds, the Bedrock Strath Surfaces, and the Onset of Deformation at the Fault Bank Locality

\begin{tabular}{|c|c|c|c|}
\hline Dated Feature & Dip, deg, & Shortening, \% & Age, kyr \\
\hline 1, Aokautere Ash & $\begin{array}{c}9.1 \\
(\mathrm{SCD})\end{array}$ & $1.26 \pm 10.3$ & $22.6 \pm 0.3$ \\
\hline $\begin{array}{l}\text { 2, Fluvial sands and silt unit } \\
\text { (envelopes Aokautere Ash) }\end{array}$ & $\begin{array}{l}<9.1 \text { to } 12.0 \\
(\mathrm{SCD}) \quad\left(4^{\mathrm{c}}\right)\end{array}$ & $\begin{array}{l}1.26 \pm 11 \text { to } \\
2.2 \pm 16.7\end{array}$ & $\begin{array}{c}<22.6 \pm 0.3 \text { to } \\
39.3 \pm 11.4\end{array}$ \\
\hline $\begin{array}{l}\text { 3, Gravel unit } \\
\text { (above bedrock strath) }\end{array}$ & $\begin{array}{l}17.0 \text { to } 19.5 \\
\left(2^{c}\right)\left(4^{c}\right)\end{array}$ & $\begin{array}{c}4.4 \pm 11.8 \text { to } \\
5.7 \pm 10.3\end{array}$ & $\begin{array}{l}78.5 \pm 18.9 \text { to } \\
103.1 \pm 23.3\end{array}$ \\
\hline 4, Bedrock strath & $\begin{array}{r}19.5 \\
\left(4^{c}\right)\end{array}$ & $5.7 \pm 10.3$ & $103.1 \pm 23.3$ \\
\hline 5, Kowai Formation & $\begin{array}{r}49.2 \\
\left(5^{c}\right)\end{array}$ & $34.7 \pm 4.1$ & $622.1 \pm 101.9^{d}$ \\
\hline \multicolumn{4}{|c|}{$\begin{array}{l}\text { The ages are derived using the orientation and age of the Aokautere Ash to determine the rate } \\
\text { of shortening ( } 5.57 \pm 0.69 \% / 100 \mathrm{kyr} \text { ) since ash deposition (approximately } 22.6 \pm 0.23 \mathrm{kyr} \text { ). The } \\
\text { total shortening, calculated from the bed dips, is divided by the rate of shortening to estimate the } \\
\text { age of each bedded unit. Uncertainties in bed dip measurements and the age of the ash are used to } \\
\text { derive the errors. The location of each numbered unit is marked on Figure } 4 \text { (circled numbers). } \\
\text { a Errors are } \pm 2^{\circ} \text {. SCD is structure contour derived, with error of } \pm 1^{\circ} \text {. } \\
\text { b This unit was preserved only on the SW side of the fault (see Figure } 4 \text { ). } \\
\text { 'Values represent number of dip measurements used to calculate the average dip values. } \\
\text { d Values are inferred top date the onset of deformation, not deposition of formation. }\end{array}$} \\
\hline
\end{tabular}

is not significant in the study area, except adjacent to faults and within mudstone lithologies that dip at angles $>60^{\circ}$. The folding is therefore modeled by assuming that departure of bedding dips from the horizontal represents a bed rotation which has taken place about a confined horizontal fold hinge zone, with little or no change in bed length. In the Waipara area, fold hinges are commonly subhorizontal $\left(<15^{\circ}\right)$ and the use of horizontal axes of bed rotation appears to be a reasonable approximation. In order to provide age estimates, we have also assumed that folding reflects constant shortening. This assumption of constant shortening represents a departure from previous studies [e.g., Wellman, 1971; Ghani, 1978], where constant rates of tilting have been inferred. However, there is almost no mechanism for accommodating constant tilting during fold growth, while it is at least possible that folding reflects constant shortening. Therefore for the purposes of this study, invariant shortening is assumed, although over the entire period of late Cenozoic deformation, this is likely to represent an oversimplification.

Shortening is calculated for a given bed length using the equation

$$
S=100(1-\cos \theta)
$$

where $S=$ shortening (in percent) and $\theta=$ bedding dip. Using the Aokautere Ash horizon data (Table 2, top row), both the amount and rate of incremental shortening are calculated for the period since ash deposition (approximately $22.6 \mathrm{kyr}$ B.P.). The rate of shortening $(5.57 \pm 0.69 \% / 100 \mathrm{kyr})$ is subse- quently extrapolated back in time to derive age estimates for the variably dipping fluvial beds below the ash (Table 2). This extrapolation also provides a first-order estimate for the age of the onset of deformation, which is observed in the underlying Kowai Formation bedrock (Table 2). Our age estimates for the fluvial deposits are supported by independent data, while the inferred age for the onset of deformation should be regarded as a crude estimate. These data are presented in Table 2.

Age Estimates. Assuming constant shortening, all of the deformation observed within the fluvial beds can be accommodated over a period of approximately $100 \mathrm{kyr}$. On the downthrown and northeast side of the fault (Figure 4), only basal parts of the fluvial stratigraphy are preserved and the Aokautere Ash is absent. To the southwest of the fault, localized hanging wall uplift has condensed the sequence, and from the marked reduction in bedding dips across the erosion surface (Figure 4) we infer that most of the 39- to 78-kyr-old stratigraphy is not preserved. It is suggested that the fluvial beds between the ash horizon and the erosion surface below range in age from approximately 22.6 to $39 \mathrm{kyr}$, while the remainder of the beds date between approximately 78 and approximately $103 \mathrm{kyr}$ (Table 2). The age of the intervening, faulted, and unconformity-bounded gravel unit (G1, Figure 4) is somewhere in the range of 39 to $78 \mathrm{kyr}$ and can be correlated across the fault where a gypsum-bearing carbonaceous horizon is found to directly overlie the gravel unit (G1). On the basis of the identification of a cold (full glacial) climate pollen spectrum (M.S. McGlone, personal communication, 
1992) sampled from the carbonaceous horizon (Figure 4), and age constraints already calculated from bracketing the sediments on the southwest side of the fault it is suggested that the carbonaceous horizon and underlying gravel unit accumulated during an episode of cold (full glacial) climate that broadly corresponds with oxygen isotope 4 (approximately 70 kyr ago).

A marked angular unconformity at the base of the fluvial beds on the southwest side of the fault signifies that the Kowai Formation bedrock is appreciably more deformed than the overlying Quaternary beds. Accordingly, the age for the onset of deformation of bedrock is inferred to be considerably older than the calculated age of the bedrock strath (approximately $103 \pm 23 \mathrm{kyr}$ ). Using the rate of shortening derived from the Aokautere Ash, all of the observable deformation of the Kowai Formation at this locality could have been achieved in the last approximately 500 to $700 \mathrm{kyr}$ (for further discussion, see Timing and Strain Rates of Deformation section).

\section{Glenray Locality}

A flight of fluvial terraces on the north bank of the Waipara River are variously tilted owing to folding associated with the development of the Waipara Syncline and adjacent anticline structures (Figure 1). The terrace surfaces display an increasing departure from the present stream gradients with vertical distance above the Waipara River floodplain. The terrace gradients are measured from profiles surveyed by automatic level, normal to the strike of folding (Figure 5). Seven principal terraces are recognized above the present floodplain of the Waipara River, five of which are displayed in Figure 5. These terraces are divided into two groups (1) the uppermost Omihi aggradation surface and (2) a flight of Waipara River degradation surfaces. The measurement error associated with surveying is conservatively estimated at $\pm 0.1 \mathrm{~m}$, while local topography on the terrace surfaces is of the order $\pm 0.5 \mathrm{~m}$. Consequently, consistent departures of terrace surface elevations in excess of $0.6 \mathrm{~m}$, which can be correlated with the locations and geometry of the underlying macroscopic folds, are inferred to reflect differential uplift associated with folding.

The most striking aspect of the terrace profile data (Figure 5) is the marked eastward climb of the Omihi Surface toward the hinge of the adjacent anticline. To the west the surface has an elevation of $70.6 \mathrm{~m}$ above mean sea level (amsl) and is approximately parallel to both the degradation surfaces and the Waipara River floodplain. Between 1.4 and $1.6 \mathrm{~km}$ from the anticline hinge the aggradation surface begins to increase in elevation, reaching a maximum elevation of $85.2 \mathrm{~m}$ (amsl), at a distance of $0.3 \mathrm{~km}$ from the hinge. This local differential uplift and the resulting tilt on the Omihi Surface appears to directly reflect growth and development of the anticline immediately west of the surface (Figure 1). By assuming that the Omihi Surface was initially horizontal in the plane of the profile, a reasonable assumption given that the surface probably developed owing to southward aggradation and the profile is oriented east-west, then it is possible to calculate the amount of local uplift at any point along the surface. The amounts of uplift are calculated relative to the Waipara Syncline hinge (the lowest point in the structure), which is assumed to represent the point of zero local (or relative) uplift and to range from 0 to $18.5 \mathrm{~m}$. Assuming an estimated age of approximately $12 \pm 2 \mathrm{kyr}$ for the Omihi Surface, uplift rates ranging from 0 to $1.54 \mathrm{~m} / \mathrm{kyr}$ ( \pm approximately $20 \%$ ) are calculated for six points on the terrace (Figure 7). However, if the gradient of the aggradation surface is extrapolated to the hinge of the adjacent anticline, then the calculated uplift rate would be 1.83 $\pm 0.52 \mathrm{~m} / \mathrm{kyr}$. This figure is remarkably close to the uplift rate $(1.70 \mathrm{~m} / \mathrm{kyr})$ derived by Yousif [1987] for the same anticline hinge $0.5 \mathrm{~km}$ to the south in Yellow Rose Creek (Figure 7). Tilting of the Omihi Surface reflects shortening rates of $0.15 \% / 100 \mathrm{kyr}$, considerably less than that calculated from the Fault Bank locality where the influence of the Omihi Fault is likely to be greater, but similar to the rates of shortening that could be inferred from bed dips of $5-10^{\circ}$ formed in the last 500-700 kyr (see Timing and Strain Rates of Deformation section for further discussion of strain rates).

In contrast to the Omihi Surface, the Waipara River degradation terrace profiles display considerably less departure from the present floodplain gradient (Figure 5). This suggests that if the rate of deformation has remained approximately constant, then the degradation terraces are considerably younger than the aggradation terrace. The radiocarbon date (1008 \pm 63 years B.P.), which is inferred to date the ponding of Limestone Creek during the formation of the second highest Waipara River degradation terrace, implies that those terrace surfaces lower in elevation than the dated terrace are less than 1000 years old. A second radiometric date derived from wood also sampled from within "ponded" deposits, but in a stream immediately adjacent to Limestone Creek, produced a similar age of $1150 \pm 55$ years B.P. (N34/f76 [Yousif, 1987]) and supports the late Holocene age assigned to the terraces. These radiocarbon dates are further supported by weatheringrind data and ${ }^{14} \mathrm{C}$ dates derived from Waipara River terraces upstream [Campbell and Nicol, 1992] and require that the river at Waipara has downcut approximately $20 \mathrm{~m}$ during the late Holocene.

\section{Mound Locality}

The Mound locality is a loess-mantled remnant of Teviotdale Surface [Wilson, 1963] which rises approximately $25 \mathrm{~m}$ above the younger and laterally extensive Canterbury Surface of late last glacial age (Figure 6a). The flanks and top of the Mound are characterized by remnant surfaces, which are tilted to the east. Below the Canterbury Surface, Waipara River degradation has resulted in the development of a series of terrace surfaces, which step down to a large (approximately 20 m) vertical river bank scarp above the present-day floodplain. Exposed in this scarp, immediately beneath the Mound, is a sequence of gravel units which displays increased deformation with age. Terrace heights and a section diagram are plotted in Figure 6a, which is constructed almost perpendicular to the strike of local folding.

Figure 6a clearly illustrates the presence of an asymmetric anticline, with westward vergence, developed within the sequence of gravels of presumed late Quaternary age. This structure was identified by Wilson [1963] and appears to be the northern continuation of a fold with a similar geometry imaged several kilometers to the south in seismic line $1 \mathrm{~A}$ of Kirkaldy and Thomas [1963]. The seismically imaged fold is 
量影

畜

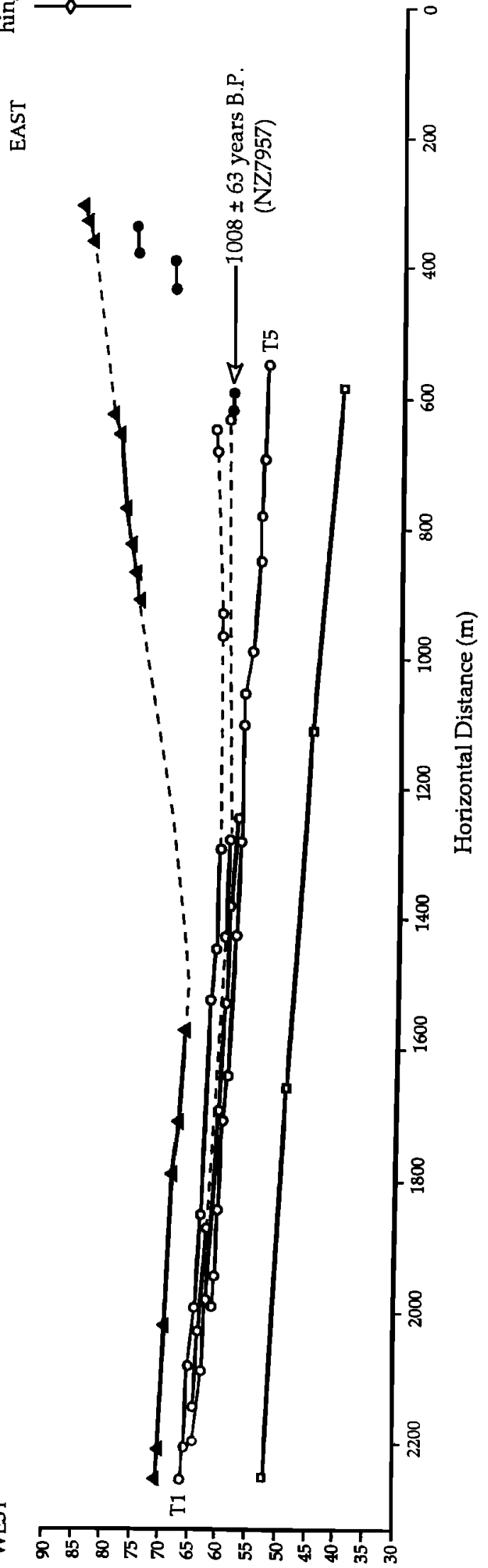

(ןsure u) чо!̣еләэ月

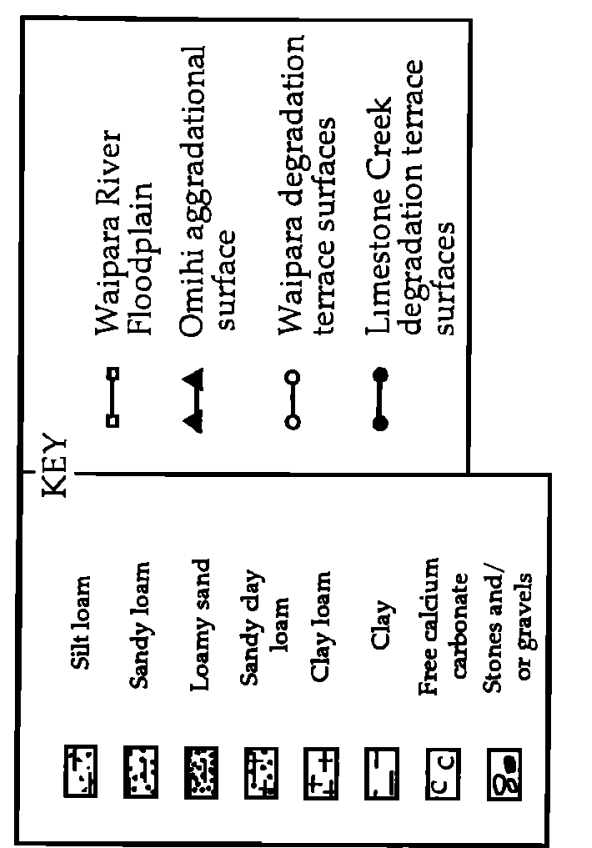

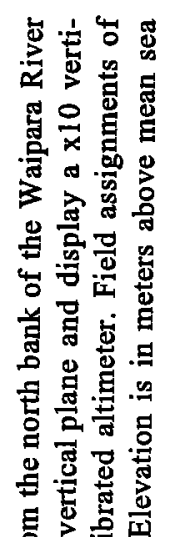

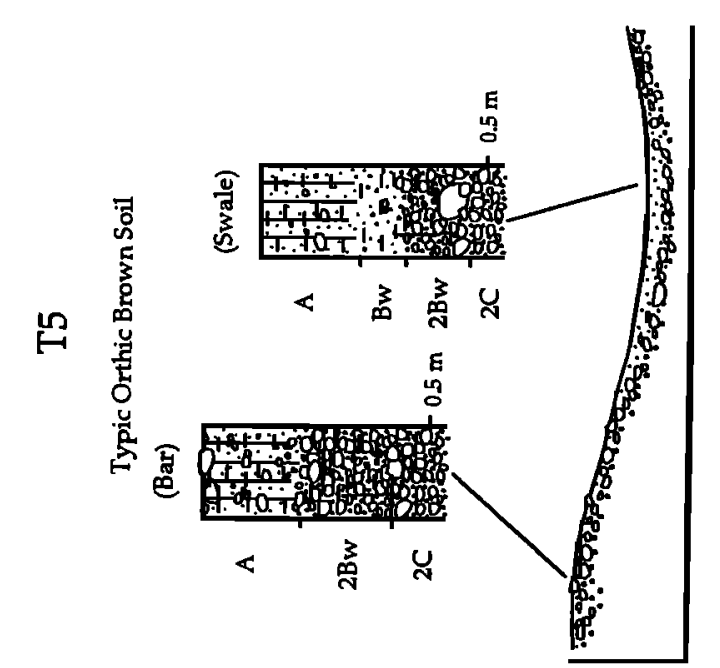

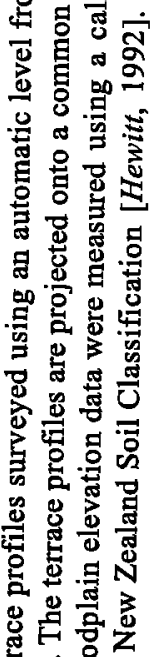

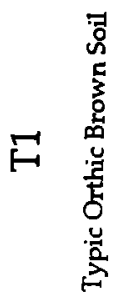

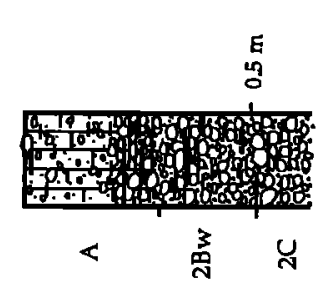

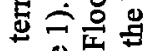

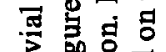

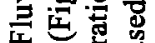

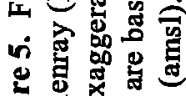

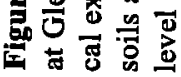

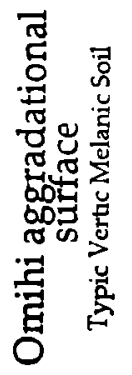

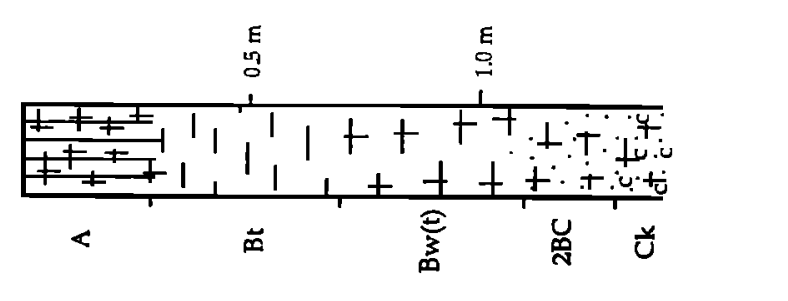




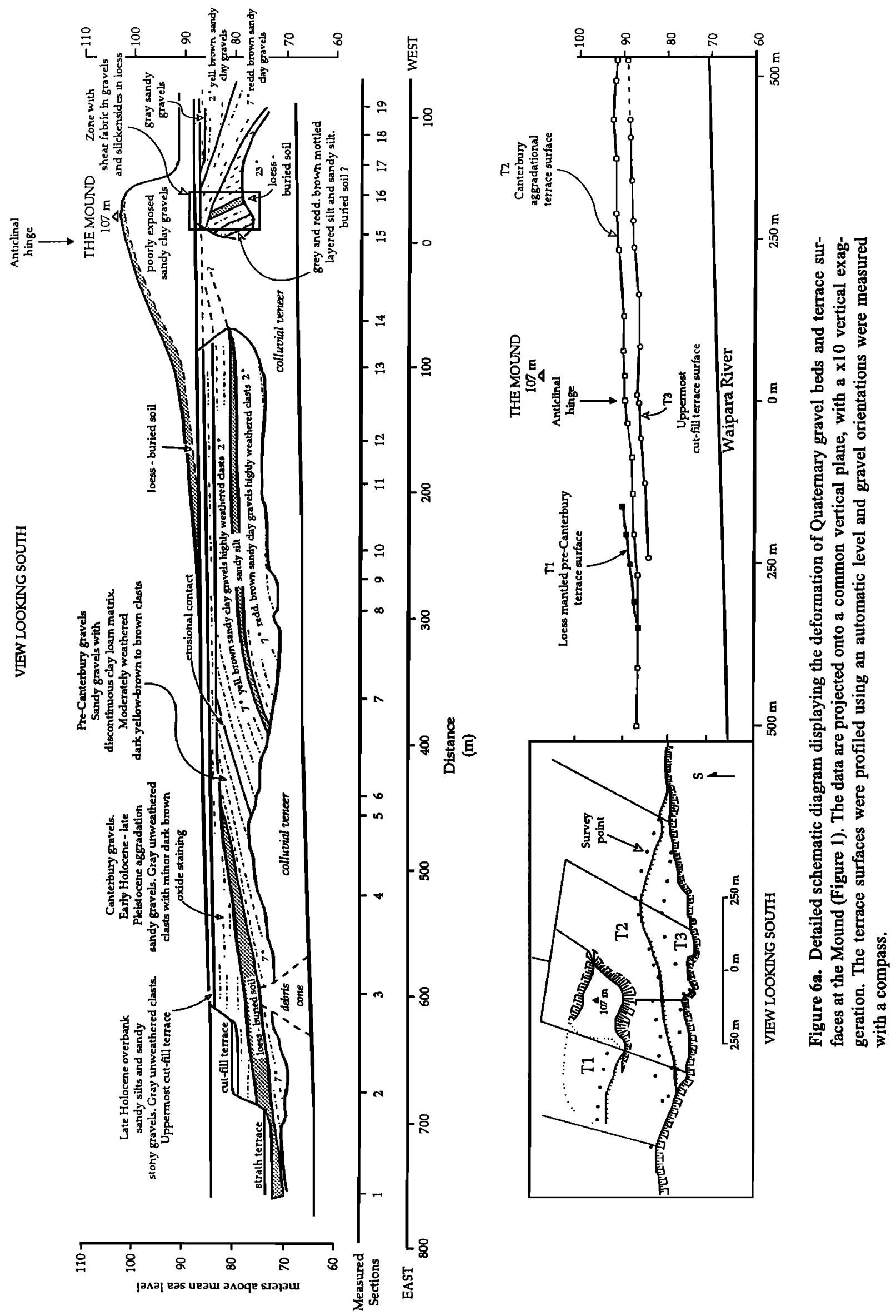


closely associated with a reverse fault that displaces the steepest limb of the asymmetric fold. We therefore infer that folding at the Mound Section reflects the presence of a macroscopic reverse fault at depth (cross section, Figure 1).

The post-Canterbury terrace surface (T3) with its thin veneer of degradation gravels appears undeformed (Figure 6a). Its strath at the anticlinal hinge unconformably overlies severely sheared pre-Canterbury weathered gravels; whereas, immediately either side of the anticline, the post-Canterbury gravel strath overlies Canterbury gravels paraconformably. Similarly, the Canterbury terrace surface (T2) across the anticlinal structure also appears undeformed, but aggradational gravels beneath this surface thin perceptibly across the hinge. Beneath the Canterbury gravels, two older gravel units are recognized and display variable dips in the vicinity of the anticlinal hinge but become increasingly parallel short distances on either side of the hinge. Intense folding and shortening are confined to a narrow zone which extends up to 200 $300 \mathrm{~m}$ on either side of the anticline hinge.

The disparity in dip between undeformed and deformed gravel units at the Mound Section could result if the rate of deformation has remained relatively constant since deposition and the age of each deformed gravel unit is markedly different from the age of gravels associated with undeformed terrace surfaces. The inference of late Quaternary deformation is supported by the geometry and inferred age of a preCanterbury terrace surface (T1, Figure 6a), located immediately east of the Mound, where its elevation relative to the underlying T2 terrace declines to the east until the two surfaces converge. East of this point, the T1 terrace is not preserved and appears to have been buried by the younger $\mathrm{T} 2$ and T3 terrace deposits (Figure 1). Tilting of T1 terrace is consistent with that of the underlying pre-Canterbury gravels, but $\mathrm{T} 1$ is covered by at least one loess sheet (approximately $3 \mathrm{~m}$ thick), the presence of which implies an age of at least 20-30 kyr old. This loess sheet can be traced east from the anticline where it dips beneath the Canterbury gravel strath. We therefore conclude that the sequence of variously deformed gravel units are indeed significantly older than the undeformed terrace surfaces and their associated gravels. The similarity in orientation of terraces T2 and T3 suggests that these two surfaces are not significantly different in age.

Soils developed on the $\mathrm{T} 2$ terrace exhibit an unexpected range of profile morphologies (Figure $6 \mathrm{~b}$ ). Some profíles exhibited a high degree of development, as evidenced by secondary clay redistribution (argillic pallic soils), whereas other soils are clearly less developed (younger) and indistinguishable from those of the uppermost degradation terrace T3 (orthic brown soils). The variations in soil development suggest that the Waipara River was either aggrading during the late Holocene or maintained a similar grade and elevation, possibly throughout the last glacial maxima and extending into the mid-Holocene. In either case the Waipara River formed a broad aggradational fan (Canterbury Surface) that was characterized by a series of back-filled channels of varying age that are accordant in height. If this is the case, then age estimates for the Canterbury aggradation surface may need to be revised downward.
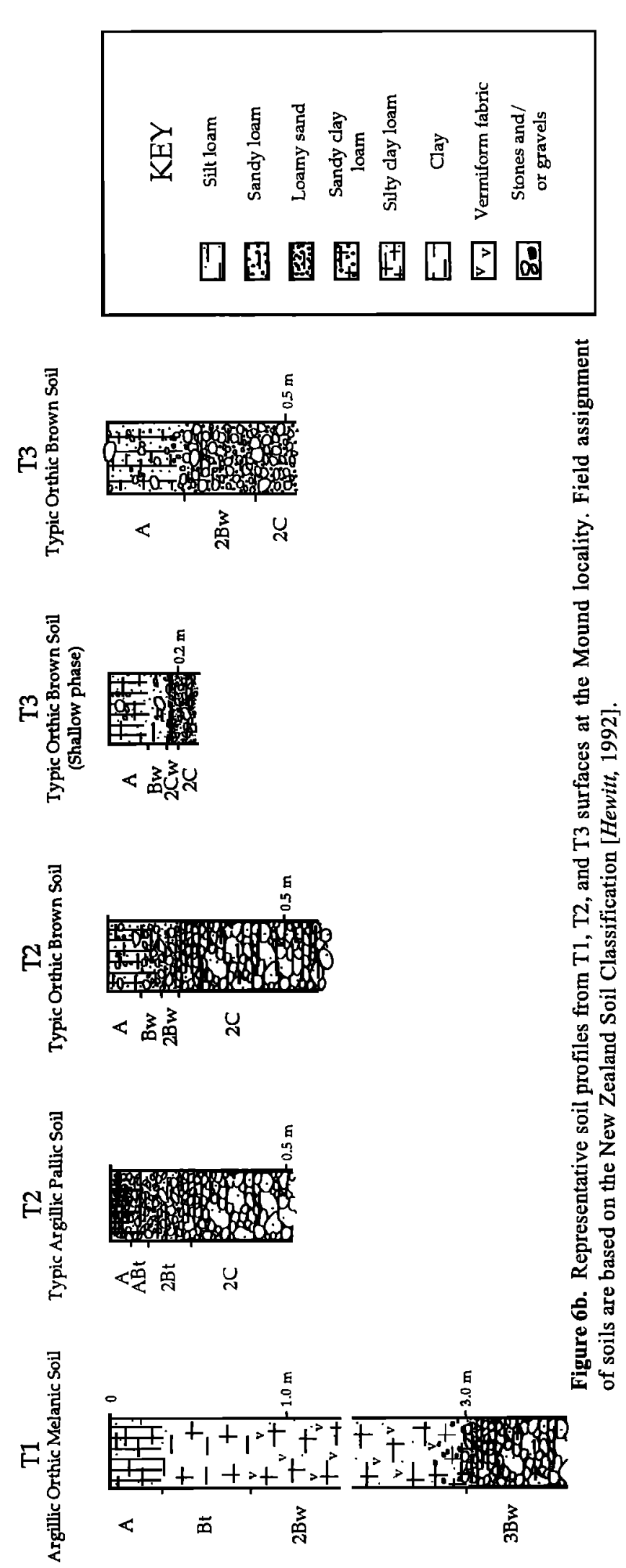


\section{Uplift Rates}

The rates of uplift calculated on the Omihi Surface at Glenray must be regarded as relative or local values, which provide information about deformation associated with folding. To derive an estimate for the total uplift, a component of regional uplift must be added to these local values [cf. Ghani, 1978]. To relate the Glenray data to the total uplift (i.e., to calculate the local and regional components of uplift), we have independently analyzed uplifted marine terraces (M1 - M3) preserved at the Pacific coast east of the study area (Figure 7).

Marine terrace elevation and age data are from Yousif [1987]. The lowest marine terrace (M1) forming the coastal plain to the east of the study area, though not directly dated, was assigned an age of approximately $60 \mathrm{ka}\left(\delta^{18} \mathrm{O}\right.$, stage 3$)$. This age is based on the presence of two overlying loess units, separated by a weak paleosol, and Aokautere Ash within the upper loess unit [Kohn, 1979]. The age of the M1 terrace is consistent with marine terrace data from Wanganui [Pillans, $1985,1988]$ which similarly show the approximately $60-\mathrm{kyr}-$ old Rakaupiko marine terrace overlain by two loess units. While there is little direct evidence for the age of the two remaining and more elevated marine terraces (M2 and M3), ages of c. 80 and $100 \mathrm{kyrs}$, respectively, are inferred using the sea level data of Chappell and Shackleton [1986] and produce uplift values which are consistent with the fold structure contour data, as well as M1 uplift rates (Figures 7 and 8). In Figure 7 the locations and inferred ages of the marine terraces are plotted on a structure contour map constructed on the base of the Pliocene (base of the Kowai Formation), modified from Wilson [1963]. A positive relationship exists between uplift rates and structure contour values. To quantify this relationship, the uplift rate is plotted against structure contour value for each location (Figure 8). The uplift rates appear to be intimately related to the underlying fold geometries (see also, Yousif [1987]). Wellman [1971], Ghani [1978] and Suggate [1987] have documented similar relationships elsewhere in New Zealand and concluded that the spatial distribution of uplift was related to the position of folds preserved in the underlying Tertiary strata. Similarly, the Waipara data also suggest that the incremental fold-related uplift is in accord with the total finite shortening, from which it is inferred that a significant component of the measurable folding developed during the current phase of regional deformation (i.e., within the Pleistocene). We conclude that, locally, the pattern of uplift principally reflects growth of the underlying folds.

If it is assumed that the range of marine terrace uplift rates $(1.36-2.16 \mathrm{~m} / \mathrm{kyr})$ reflects principally the location of the terraces relative to the folds, then the points of zero local uplift (i.e., macroscopic syncline hinge zones) and maximum total uplift (i.e., macroscopic anticline hinge zones) can be located and their values estimated. However, because not all structure contours have been sampled, the linear relationship determined in Figure 8 (line b) must be extrapolated to the highest and lowest structure contour values, assuming a constant line gradient to estimate the complete range of uplift rates. The maximum structure contour estimate is derived by sampling from the structurally highest point on the Cass Anticline (structure contour approximately $890 \mathrm{~m}$ ), while determining the minimum structure contour value is more difficult, as the syncline immediately east of the marine terraces is offshore and the Waipara Syncline, which plunges gently to the SSW, is spatially removed from the uplift data. For the purposes of this work we have assumed that the base of the fold-enveloping surface is approximately horizontal between Waipara and the coastline and use a range of minimum structure contour values from -250 to $-650 \mathrm{~m}$. This range represents values in the Waipara Syncline adjacent to the Cass Anticline maxima and is used to calculate the estimated minimum uplift. At the intersection of these structure contour estimates and the statistical line of best fit (Figure 8, line b), two uplift values are inferred, a minimum of 0.68-1.20 $\pm 0.2 \mathrm{~m} / \mathrm{kyr}$ and a maximum of $2.68 \pm 0.2 \mathrm{~m} / \mathrm{kyr}$. These uplift rate estimates are an order of magnitude larger than those derived by Wellman [1979] for the same region but are in broad agreement with uplift rates calculated immediately to the north [Ota et al., 1984] and southwest [Cowan, 1992a]. The maximum value, $2.68 \pm 0.2$ $\mathrm{m} / \mathrm{kyr}$, is inferred to approximately equal the maximum uplift rate for the region between Waipara and the coast (i.e., the coastal ranges). The minimum uplift rate is regarded as the lowest local uplift rate. At the location of minimum uplift the local component of uplift is approximately zero and the total uplift is approximately equal to the regional component. The regional component of uplift at Waipara is therefore inferred to be between 0.68 and $1.20 \mathrm{~m} / \mathrm{kyr}$, and local uplift may account for up to approximately $55-75 \%$ of the total. However, the component of local uplift in the total is expected to decline significantly westward as the regional uplift associated with the Alpine Fault and development of the Southern Alps increases.

A comparison of the uplift rates for the Omihi surface and marine terraces (Figure 8, lines a and b) illustrates a disparity between these two data sets with respect to the structure contour values; where for a given range of structure contour values, the Omihi Surface uplift rates are greater than those of the marine terraces. Such a disparity would be expected if the uplift rates of the Omihi Surface were high (relative to the average rates of uplift for this part of the fold) during the Holocene. Locally high uplift rates could have been induced by southward propagation of the Omihi Fault and a corresponding westward migration of the range front into the Waipara valley.

The present analysis of uplift has two important implications for improving our understanding of the analysis and interpretation of uplift in areas of active folding. Previously, the analysis of uplift in New Zealand has mainly been confined to areas where geomorphic marker surfaces, such as marine and fluvial terraces of known age, are present. Although extremely useful, this has obvious limitations because these surfaces are usually of limited extent and are rarely preserved in areas of greatest uplift. We suggest that the analysis presented in Figure 8 may form the basis of a technique designed to produce uplift rate contour maps in areas where limited uplift data are available. The accuracy of such uplift maps would depend on the errors associated with the uplift and structure contour estimates, the correlation coefficient of the two variables, and proximity of the map to the raw data. It is possible that these maps will provide a first approximation to uplift patterns on a regional scale $\left(50-100 \mathrm{~km}^{2}\right)$, although in areas where temporal changes in the uplift rates have occurred the map could require modification. We must also add a caution- 


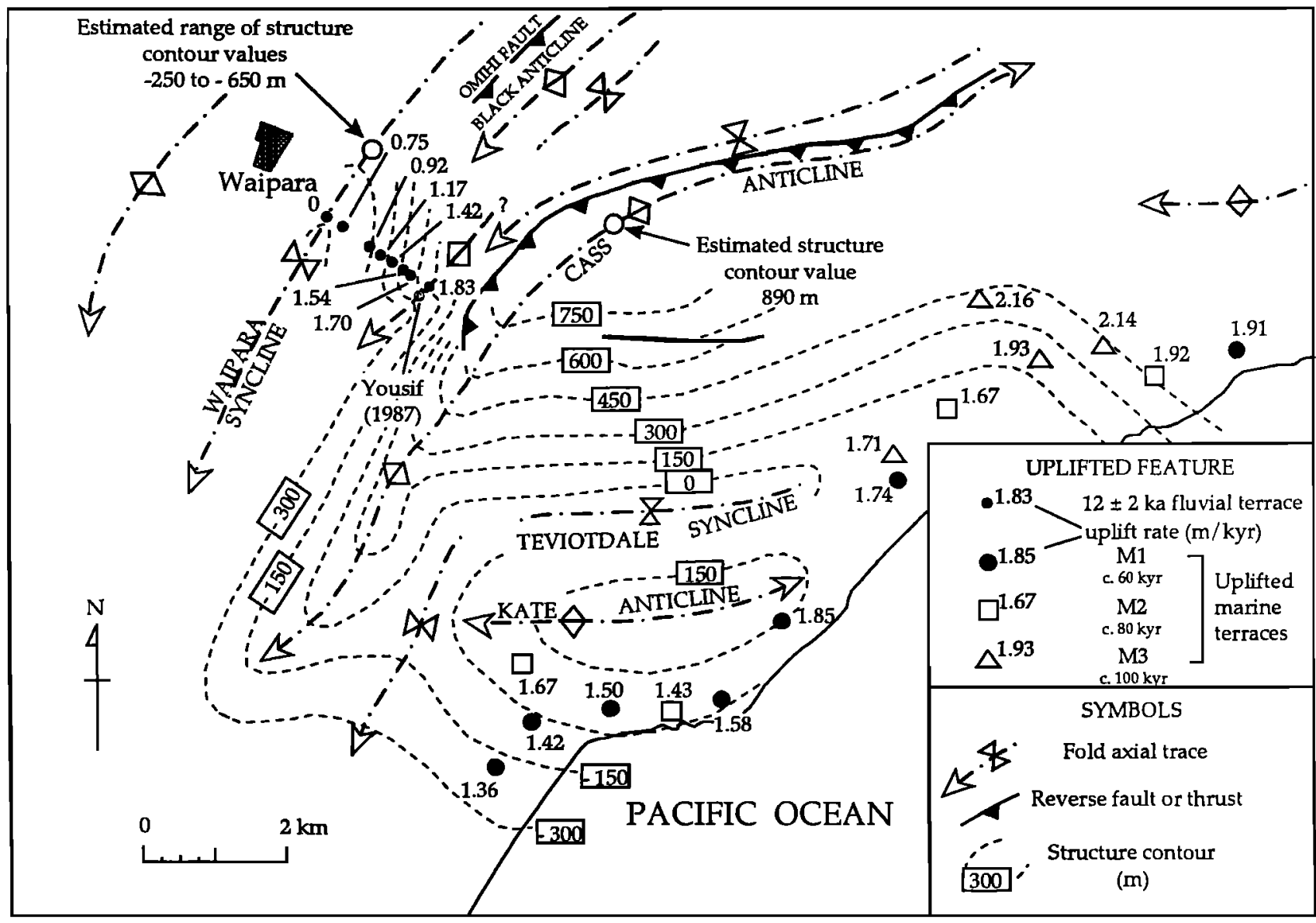

Figure 7. A comparison of the spatial distribution of uplift rates, derived from both fluvial and marine terraces, and fold locations as indicated by structure contour values. The structure contours are constructed on the base of the Pliocene (base of the Kowai Formation) and are modified from Wilson [1963]. Uplift rates are indicated in meters per kyr next to each uplifted terrace feature. See text (Uplift Rates section) for further explanation.

ary note concerning uplift rates derived from areas of active folding, particularly where the rates of regional uplift are relatively small. It is quite clear that, locally, uplift rates vary considerably. In this study, uplift rates are inferred to range from 0.68 to $2.68 \mathrm{~m} / \mathrm{kyr}$ across the active folds in the coastal ranges. To derive a rate of uplift, locally, as would be the case for most marine or fluvial terrace data, and to use this value in a regional analysis of uplift could produce misleading results. Therefore extreme caution should be exercised when comparing rates of uplift spatially without an understanding of where the uplift estimates were derived relative to the local fold structures.

\section{Timing and Strain Rates of Deformation}

Although there is stratigraphic evidence for tectonic activity in North Canterbury during the Miocene and Pliocene [e.g., Andrews, 1963; Wilson, 1963; McCulloch, 1981; Browne and Field, 1985], it appears unlikely that measurable faulting and folding began prior to the early Pleistocene [Nicol, 1992; Cowan, 1992a, b]. This early Pleistocene age represents the upper age limit of the Kowai Formation, which based on outcrop scale observations is everywhere conformable with the underlying formations at similar locations with respect to the macroscopic folds. It has been suggested therefore that the onset of measurable deformation postdates deposition of much of the Kowai Formation [Nicol, 1992]. This formation is everywhere poorly dated, but upper parts of the unit are inferred by several workers [Wilson, 1963; Gregg, 1964; Browne and Field, 1985] to be Nukumaruan (approximately 1.4 - 2.4 m.y. old [see Pillans, 1990]). Conservatively, this would place the onset of deformation at an age younger than $2.4 \mathrm{~m} . y$.

Data collected during this study suggest that the development of faults and folds may be as young as approximately 0.5-0.8 m.y. Two independent sets of data support this conclusion. Firstly, by using the rates of shortening derived at the Fault Bank locality and extrapolating these back in time (assuming a constant rate of shortening), all of the deformation observed within the Kowai Formation can be achieved in 


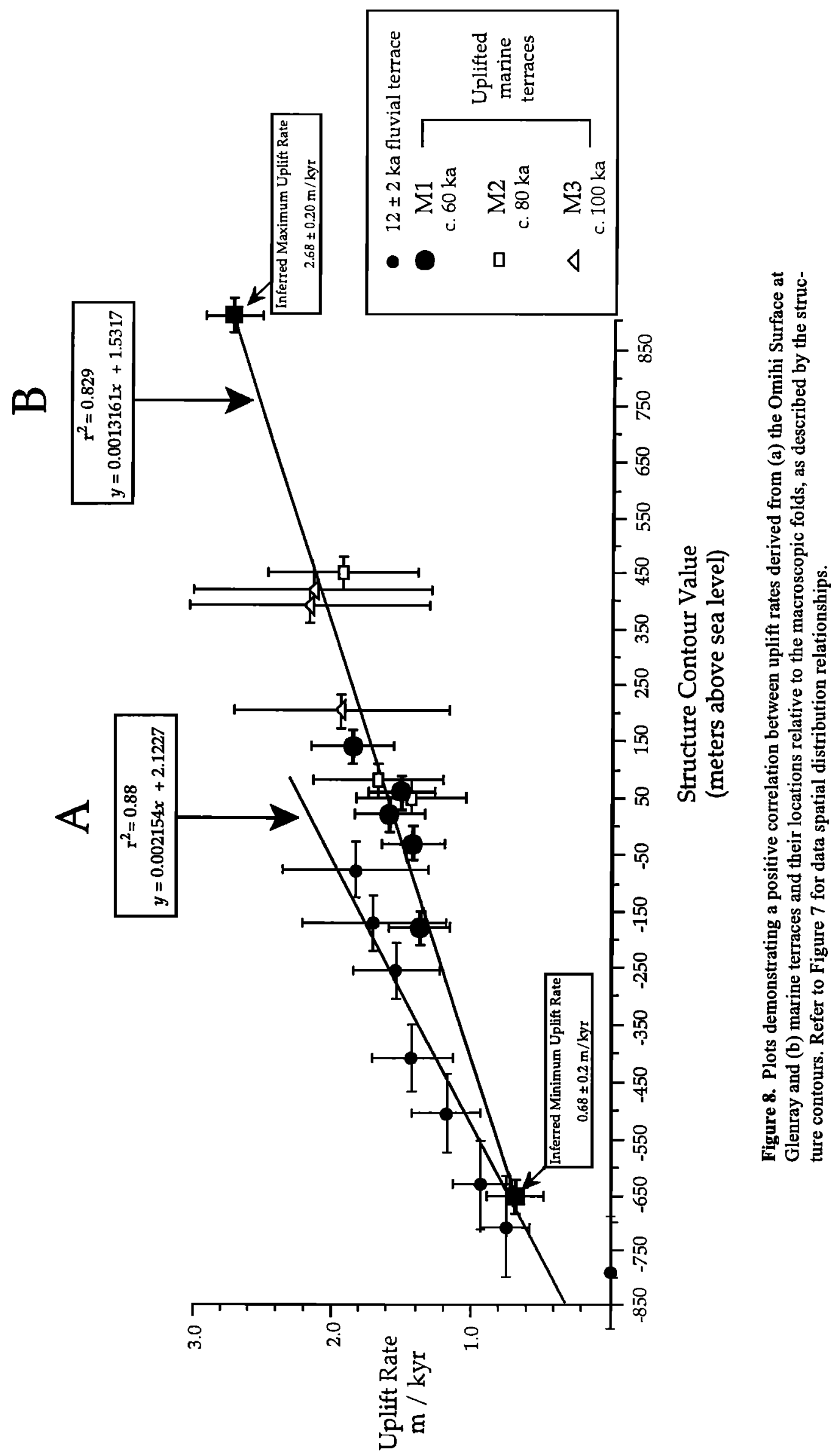


approximately $0.62 \pm 0.10 \mathrm{~m} . \mathrm{y}$. (Table 2 ). A second estimate is derived from the $1340 \pm 250 \mathrm{~m}$ structural elevation difference between the Cass Anticline and Waipara Syncline and a differential uplift rate of $1.74 \pm 0.5 \mathrm{~m} / \mathrm{kyr}$ (2.68-0.94). By assuming that the rate of differential uplift across the folds was constant for the duration of deformation, we estimate that folding was initiated between 0.5 and $1.3 \mathrm{~m}$.y. ago. Although both calculations require assumptions that are likely to represent oversimplifications, we suggest that, collectively, these data provide a basis for first approximation of the onset of deformation. We favor a first-order age of $0.8 \pm 0.4 \mathrm{~m} . \mathrm{y}$. for the onset of deformation in this part of North Canterbury. Similar ages have been inferred for the initiation of rapid uplift of the North Island axial ranges [e.g., Ghani, 1978; Beu et al., 1981] and the West Coast, South Island [Nathan et al., 1986]. These age data suggest that a dramatic increase in the rates of shortening and uplift occurred along much of the plate boundary in New Zealand within the last 1 m.y.

Our age data are combined with shortening estimates (approximately 6\%), measured along the base of the Kowai Formation from the cross section in Figure 1 and structural contours in Figure 7, to derive strain rates across the coastal ranges. A shortening rate of approximately $0.8 \pm 0.4 \% / 100$ kyr is calculated, a value intermediate between the rates determined at the Fault Bank $(5.57 \% / 100 \mathrm{kyr})$ and Glenray $(0.15 \% / 100 \mathrm{kyr})$ localities. About $1 \mathrm{~km}$ of absolute shortening has occurred across the coastal ranges at Waipara over a distance of $16-17 \mathrm{~km}$, at an average rate of approximately 1.4 $\pm 0.6 \mathrm{~m} / \mathrm{kyr}$. This rate represents only a small proportion of the predicted plate motion vector of about $38 \mathrm{~m} / \mathrm{kyr}$ [De Mets et al., 1990], as is to expected on the edge of the plate boundary zone. However, immediately to the north and west of Waipara, shortening of $10-20 \%$ is more common [Nicol, 1991], and assuming that the deformation is not significantly older, rates of shortening of $3-5 \mathrm{~m} / \mathrm{kyr}$ may be more representative.

\section{Influence of Deformation on Cover Bed Stratigraphy and Geomorphology}

Although folds appear locally to have developed in response to faulting at depth, the predominance of folds at the surface and the way in which deformation is laterally distributed by folding have a profound influence on surface processes. Active folding plays an integral part in establishing the distribution and morphology of both geomorphic surfaces and associated cover beds of varying ages in North Canterbury.

As tectonic uplift is closely related to folding, so, too, must the spatial distribution of erosion and sedimentation be significantly influenced by folding. Throughout North Canterbury, anticline hinges are marked by eroding ranges or ridges, while synclines are coincident with valleys or basins that contain late Pleistocene aggradation gravels. These gravels often form angular discordances of $2-30^{\circ}$ with Tertiary bedrock (e.g., at the Fault Bank locality, Figure 4), which suggests that the onset of sedimentation postdated the initiation of folding and shortening. Therefore the gravels are necessarily younger than $0.9 \pm 0.4 \mathrm{~m} . \mathrm{y}$; ; at the Fault bank locality, sedimentation is inferred to postdate the onset of deformation by about $0.5 \mathrm{~m}$.y. Similarly, the coastal ranges east of Waipara must be older than the oldest valley fill, which from the Fault Bank locality appears to be approximately $100 \mathrm{kyr}$. Where observed bedrock/late Pleistocene gravel contacts invariably dip toward adjacent synclines, Quaternary cover beds are thickest above the active synclinal fold hinges and thin toward the anticlinal hinges. Evidence for this is provided by the absence of Quaternary deposits on or adjacent to the anticlines and by the absence of bedrock along the banks of the Waipara River within each of the synclines. The height of the first terrace above the south bank of the Waipara River suggests that Quaternary gravel deposits reach a thickness of at least $20-30 \mathrm{~m}$. By extrapolating the dip of the bedrock strath surface to the syncline hinges it is estimated that, locally, gravel thicknesses may reach maximum values of 80-140 m above syncline hinges (Figure 1, cross section).

Geomorphic surfaces examined during this study appear to have formed within the last $100 \mathrm{kyr}$ and are young relative to the age of onset of deformation. Owing to active folding, fluvial surfaces of $>10 \mathrm{kyr}$ are most often preserved on the flanks of anticlines. Local evidence for burial of fluvial surfaces close to synclines is provided at the Mound Section, where a loess-covered surface passes beneath a degradation surface of younger age (Figure 6a). Conversely, late Pleistocene cover beds and fluvial terraces are currently being uplifted and eroded along the Waipara range front.

Below the Omihi aggradation surface, flights of degradation terraces step down to the present Waipara River floodplain. The degradation surfaces are generally characterized by rudimentary stony soil profiles which strongly suggest late Holocene age. Two radiocarbon dates, each of about $1 \mathrm{kyr}$ B. P. also suggest that most of these degradation surfaces are of late Holocene age. At Waipara the Waipara River has downcut approximately $20 \mathrm{~m}$ in the last $1 \mathrm{kyr}$, which would require an average downcutting rate of $2 \mathrm{~m} / 100$ years over this period. The reason for this period of rapid downcutting is not clear, although it may be that river incision was triggered by uplift associated with the last fold growth event on the adjacent anticline. If this is so, then the question remains as to why there is little evidence of previous Holocene downcutting events along this part of the Waipara River. Few data are presently available to address this problem, and we cannot discount the possibility that close to the Waipara Syncline the Waipara River has experienced periods of both aggradation and degradation during the Holocene. Rapid late Holocene downcutting requires that despite continued deformation the Waipara River remained at or close to the level of the late Pleistocene aggradation surface for possibly as long as $10 \mathrm{kyr}$. It is also reasonable to speculate that rapid downcutting of the Waipara River during the late Holocene might have been influenced by two narrow, structurally controlled gorges that confine the river on either side of the Waipara Syncline and control rates of sediment flux.

\section{Conclusions}

Rates of folding in the Waipara area during the late Quaternary are measured using tilted and uplifted fluvial terraces, marine terraces, and cover beds. Our data suggest that 
the spatial and temporal distribution of deformation is variable. The highest rates of deformation occur along the Waipara range front, where bedrock deformation is most intense. Shortening rates reach up to $5.57 \pm 0.69 \% / \mathrm{kyr}$ and average $0.8 \pm 0.4 \% / 100 \mathrm{kyr}$ across the coastal ranges. This average is indicative of an absolute shortening rate of $1.4 \pm 0.6$ $\mathrm{m} / \mathrm{kyr}$, which represents only a small proportion of the predicted plate motion vector in this region but may increase to 3-5 $\mathrm{m} / \mathrm{kyr}$ immediately to the north and west. Uplift rates range from 0 to $1.83 \mathrm{~m} / \mathrm{kyr}$ for a late last glacial fluvial terrace and from 1.36 to $2.16 \mathrm{~m} / \mathrm{kyr}$ for three marine terraces. Both fluvial and marine terrace uplift rates vary in accord with the geometries of folds in the bedrock, and the spatial pattern of uplift directly reflects fold growth. In these circumstances a first approximation to the spatial pattern of uplift may be derived from the structure contour pattern of beds across the folds. Fold-related differential uplift accounts for up to approximately $55-75 \%$ of the total uplift and has produced folds with structural relief of about $1300 \mathrm{~m}$. These folds have formed over the last $0.8 \pm 0.4 \mathrm{~m} . \mathrm{y}$. since the onset of late Cenozoic deformation in the Waipara region. The coastal ranges and Waipara valley, with its associated gravel deposits, owe their existence to folding and therefore must postdate the onset of deformation.

Acknowledgments. Funding for this work was provided by the Earthquake Research Foundation (A.N.), a Soil Science Department and Lincoln University Postdoctoral fellowship (B.V.A.), and Lincoln University Internal Research grants (P.J.T.). We would like to thank the Berry, Ensor, Forbes, Harris, Millist, and Watson families for cheerfully allowing access to their properties; Hugh Cowan and Jocelyn Campbell for many stimulating discussions during the course of this work; Dave Manning and Paul Froggatt for electron microprobe analyses; Bernard Spörli, Brad Pillans, and Hugh Cowan for reviewing an earlier version of this manuscript; and, finally, Kelvin Berryman and Tracy Vallier, who reviewed the final manuscript.

\section{References}

Alloway, B. V., B. J. Pillans, A. S. Sandhu, and J. A. Westgate, Revision of the marine chronology in the Wanganui Basin, New Zealand, based on the isothermal plateau fission-track dating of tephra horizons, Sediment. Geol., 82, 299-310, 1993.

Alloway, B. V., D. J. Lowe, R P. K. Chan, D. Eden, and P. C. Froggatt, Stratigraphy and chronology of the Stent tephra, a c. 4000 year old distal silicic tephra from Taupo Volcanic Centre, New Zealand, N.Z. J. Geol. Geophys., 37, 37-47, 1994.

Andrews, P. B., Stratigraphic nomenclature of the Omihi and Waikari Formations, North Canterbury, N.Z. J. Geol. Geophys., 6, 228256, 1963.

Berryman, K.R., Age, height, and deformation of Holocene marine terraces at Mahia Peninsula, Hikurangi Subduction margin, New Zealand, Tectonics, 12, 1347-1367, 1993a.

Berryman, K.R., Distribution, height, and deformation of late Pleistocene marine terraces at Mahia Peninsula, Hikurangi Subduction margin, New Zealand, Tectonics, 12, 1365-1379, 1993b.

Beu, A. G., G. H. Browne, and T. L. GrantTaylor, New Chlamys delicatula localities in the central North Island and uplift in the Ruahine Range, N.Z. J. Geol. Geophys., 24, 127-132, 1981.

Browne, G. H., and B. D. Field, The lithostratigraphy of late Cretaceous to early Pleistocene rocks of North Canterbury, New Zealand, N.Z. Geol. Surv. Rec., 6, Wellington, 1985.

Campbell, I. B., New occurrences and distribution of Kawakawa Tepbra in South Island, New Zealand, N.Z. J. Geol. Geophys., 29, 425-435, 1986.
Campbell, J.K., and A. Nicol, Holocene folding and rupture on the Bobys Creek Fault and related Quaternary deformation along the Waipara River, in Field Trip Guides: Geological Society of New Zealand and New Zealand Geophysical Society 1992 Joint Annual Conference, edited by J. K. Campbell, Misc. Publ. 63B, pp. 137- 153, Geol. Soc. of N.Z., Christchurch, 1992.

Chappell, J., and N. J. Shackleton, Oxygen isotopes and sea level, Nature 324, 137-140, 1986.

Chinn, T. J. H., Use of rock weathering-rind thickness for Holocene absolute age-dating in New Zealand, Arct. Alp. Res., 13, 33-45, 1981.

Cowan, H. A., Structure, seismicity and tectonics of the Porter's Pass - Amberley Fault Zone, Ph.D. thesis, Univ. of Canterbury, Christchurch, N.Z., 1992a.

Cowan, H. A., Quaternary expansion of the New Zealand plate boundary zone into North Canterbury, in Conference Abstracts: Geological Society of New Zealand and New Zealand Geophysical Society 1992 Joint Annual Conference, edited by J. K. Campbell, Misc. Publ. 63A, Geol. Soc. of N.Z., Christchurch, 1992b.

De Mets, C., R. G. Gordon, D. F. Angus, and S. Stein, Current plate motions, Geophys. J. Int., 101, 425-478, 1990.

Eden, D. N., A Late Quatemary history of the Awatere and Wairau Valleys, Marlborough, New Zealand, Ph.D. thesis, Victoria Univ. of Wellington, Wellington, N.Z., 1983.

Froggatt, P. C., and D. J. Lowe, A review of late Quatemary silicic and some other tephra formations from New Zealand: Their stratigraphy, nomenclature, distribution, volume and age, N.Z J. Geol. Geophys., 33, 89-109, 1990.
Ghani, M. A., Late Cenozoic vertical crustal movements in the southem North Island, New Zealand, N.Z. J. Geol. Geophys., 21, 117-125, 1978.

Gregg, D. R., Sheet 18, Hurunui (1st ed.) Geological map of New Zealand, scale 1:250000, Dep. Sci. and Ind Res., Wellington, N.Z., 1964.

Harris, M.H., Canterbury Gravels at Omihi Stream, Waipara, Diploma of Sci. thesis, Univ. of Otago, Dunedin, N.Z., 1982.

Hewitt, A.E., New Zealand soil classification, Land Resour. Sci. Rep., 19, 133 pp., Dep. of Sci. and Ind. Res., Wellington, N. Z., 1992.

Kirkaldy, P. H. S., and F. G. Thomas, Final report on a seismic survey in the Canterbury Plains area of New Zealand, Geol./Geophys. Rep. 27, BP Shell and Todd Pet. Dev. Ltd, Wellington, N.Z., 1963.

Knuepfer, P. L. K., Estimating ages of late Quaternary stream terraces from analysis of weathering rinds and soils, Geol. Soc. Am. Bull., 100, 1224-1236, 1988.

Kohn, B. P., Identification and significance of a late Pleistocene tephra in the Canterbury District, South Island, New Zealand, Quat. Res., 11, 78-92, 1979.

Lewis, K. B., Growth rate of folds using tilted wave-planed surfaces: Coast and continental shelf, Hawke's Bay, New Zealand, Bull. R. Soc. N.Z., 9, 225-231, 1971.

Maxwell, P.A., Structural geology and preQuatemary stratigraphy of the Kaiwara District, North Canterbury, New Zealand, M.Sc. thesis, Univ. of Canterbury, Christchurch, N.Z., 1964.

McCulloch, B., Geology of the Mt. Brown Beds, M.Sc. thesis, Univ. of Canterbury, Christchurch, N.Z., 1981.

Mew, G., J. L. Hunt, P. C. Froggatt, D. N. Eden, and R. J. Jackson, An occurrence of 
Kawakawa Tephra from the grey River valley, South Island, New Zealand, N.Z. J. Geol. Geophys., 29, 315-322, 1986.

Milne, J. D. G., Upper Quaternary geology of the Rangitikei drainage basin, North Island, New Zealand, Ph.D. thesis, Victoria Univ. of Wellington, Wellington, N.Z., 1973.

Nathan, S., H. J. Anderson, R. A. Cook, R. H. Herzer, R.H. Hoskins, J. I. Raine, and D. Smale, Cretaceous and Cenozoic sedimentary basins of the West Coast region, South Island, New Zealand, in New Zealand Geological Survey Basin Studies, 1 , Department of Scientific and Industrial Research, Wellington, New Zealand, 1986.

Nicol, A., Structural styles and kinematics of deformation on the edge of the New Zealand plate boundary zone, mid-Waipara region, North Canterbury, Ph.D. thesis, Univ. of Canterbury, Canterbury, N.Z., 1991.

Nicol, A., Tectonic structures developed in Oligocene limestones: Implications for New Zealand plate boundary deformation in North Canterbury, N.Z. J. Geol. Geophys., 35, 353-362, 1992.

Ota, Y., T. Yoshikawa, N. Iso, A. Okada, and N. Yonekura, Marine terraces of the Conway coast, South Island, New Zealand, N.Z. J. Geol. Geophys., 27, 313-325, 1984.

Palmer, A. S., Kawakawa Tephra in Wairarapa, New Zealand, and its use for correlating Ohakea Loess, N.Z. J. Geol. Geophys., 25, 305-315, 1982.

Pillans, B. J., Southwest North Island paleoenvironments 150,000 years B.P. to present, in Proceedings of the 2nd CLIMANZ Conference, edited by B. J.
Pillans, Publ. 3I, pp. 37-43, Geol. Dep., Victoria Univ. of Wellington, Wellington, N.Z., 1985.

Pillans, B. J., Loess chronology in Wanganui Basin, New Zealand, in Loess: Its Distribution. Geology and Soils, edited by D. N. Eden and R. J. Furkert, Proceedings of the International Symposium on Loess, New Zealand, 14-21 February 1988, pp. 175-191, A. A. Balkema, Rotterdam, Netherlands, 1988.

Pillans, B. J., New Zealand Quaternary stratigraphy: An overview, Quat. Sci. Rev., 10, 405-418, 1990.

Pillans, B. J., M. S. McGlone, A. S. Palmer, D. Mildenhall, B. V. Alloway, and G. Berger, The last glacial maximum in central and southem North Island, New Zealand: A paleoenvironmental reconstruction using Kawakawa Tephra Formation as a chronostratigraphic marker, Palaeogeogr., palaeoclimatol., palaeoecol., 101, 283-304, 1993.

Singh, L. J., Uplift and tilting of the Oterei coast, Wairarapa, New Zealand, during the last ten thousand years, in Recent Crustal Movements, edited by B. W. Collins and R. Frazer, Bull. R. Soc. N.Z., 9, 25-30, 1971.

Suggate, R.P., Active folding in North Westland, New Zealand, N.Z. J. Geol. Geophys., 30, 169-174, 1987.

Wellman, H. W., Holocene tilting and uplift on the Glenburn coast, Wairarapa, New Zealand, in Recent Crustal Movements, edited by B. W. Collins and R. Frazer, Bull. R. Soc. N.Z., 9, 211-215, 1971.

Wellman, H. W., An uplift map for the South Island of New Zealand, and a model for uplift of the Southern Alps, in Origin of the Southem Alps, edited by R. I. Walcott and M. M. Cresswell, Bull. R. Soc. N.Z., 18, 1320, 1979.

Wilson, C. N., V. R. Switsur, and A. P. Ward, A new date for Oruanui (Wairakei) eruption, New Zealand, Geol. Mag., 125, 297-300, 1988.

Wilson, D. D., The northern continuation of the Canterbury Plains, Canterbury, New Zealand, N.Z. J. Sci. Technol., 37, 126131, 1955.

Wilson, D. D., The geology of the Waipara Subdivision (Amberley and Motunau sheets S68 and S69), N.Z. Geol. Surv. Bull.. 64, 122 pp., 1963.

Yousif, H.M.S., The applications of remote sensing to geomorphological neotectonic mapping in North Canterbury, Ph.D. thesis, Univ. of Canterbury, Canterbury, N.Z., 1987.

B. V. Alloway, Department of Geology, Auckland University, Tamaki Campus, Private Bag 92019, Auckland, New Zealand. (e-mail: b.alloway@auckland.ac.nz)

A. Nicol, Earth Sciences Department, University of Liverpool, Liverpool, England L69 3BX.

P. J. Tonkin, Department of Soil Science, Lincoln University, PO Box 84, Canterbury, New Zealand.

Received December 16, 1993;

revised May 12, 1994;

accepted May 24, 1994.) 